Brief Report

\title{
Straightforward Synthesis of Bifunctional Phosphorus Phenols via Phosphination of In Situ Generated $o$-Quinone Methides
}

\author{
Zhangpei Chen *, Qinglong Shi, Gongshu Wang, Siwen Chen and Jianshe Hu * \\ Center for Molecular Science and Engineering, College of Sciences, Northeastern University, \\ Shenyang 110819, China; 1600210@stu.neu.edu.cn (Q.S.); 1770058@stu.neu.edu.cn (G.W.); \\ 1770035@stu.neu.edu.cn (S.C.) \\ * Correspondence: chenzhangpei@mail.neu.edu.cn (Z.C.); hujs@mail.neu.edu.cn (J.H.); Tel.: +024-8368-3429 \\ (Z.C. \& J.H.)
}

Received: 15 May 2018; Accepted: 18 May 2018; Published: 23 May 2018

\begin{abstract}
An efficient and practical approach towards bifunctional phosphorus phenols has been developed through a reaction of diphenylphosphine oxide and the $o$-quinone methides in situ generated from 2-tosylalkyl phenols under basic conditions. This protocol features simple experimental procedures under mild conditions and is easily scaled up. With this method, a variety of diarylmethyl phosphine oxides can be produced with up to $92 \%$ yield.
\end{abstract}

Keywords: o-quinone methides; 2-tosylalkyl phenols; phosphorus phenols; diphenylphosphine oxide; organophosphorus compounds

\section{Introduction}

Since the pioneering work of Wittig, organophosphorus compounds have emerged to be enormously important for various areas in chemistry and resonate across numerous disciplines [1-4]. Among them, phosphine oxides have attracted considerable attention due to their wide structural diversity and properties. In recent years, an increasing number of documents on the application of phosphine oxides in ligand chemistry [5,6], pharmaceutical chemistry [7-9], organic synthetic chemistry, and materials science have been demonstrated $[10,11]$. In particular, aside from the well-known triphenylphosphine oxide, plenty of novel phosphine oxides have been designed and synthesized as useful molecules for both industry and academia. For example, the chiral phosphine oxide compound A (BINAPO) [12] and the bisoxazoline phosphorus ligand $\mathbf{B}$ [13] have been employed as a catalyst or ligand to catalyze versatile asymmetric reactions; the phosphorus chromones $\mathbf{C}$ is a progesterone receptor antagonist [14]; compound $\mathbf{D}$ is known as a preeminent flame retardant [15] (Figure 1).

Accordingly, the preponderance of phosphine oxides has expedited the exploration of efficient and environmentally benign synthetic methods for their preparation [16-20]. Although much progress has been achieved in this chemistry, only a few approaches have been developed for the synthesis of arylated-methyl phosphine oxides, particularly diaryl and triarylmethyl phosphine oxides. Some classical approaches include the Michaelis-Arbuzov or Michaelis-Becker reaction [21,22] and the $\mathrm{FeCl}_{3}$-mediated Friedel-Crafts reaction [23] (Scheme 1a). However, these reactions require harsh reaction conditions and are limited to a narrow substrate scope. Walsh's group developed the Pd-catalyzed $\alpha$-arylation of benzylic phosphine oxides with haloarenes in medium to good yield [24]. Although this method involves a relatively wide substrate scope, the use of expensive metal catalysts and difficulty of scaling up make it unattractive. Recently, the Anand [25] and Kang groups [26] revealed 1,6-hydrophosphonylation of para-quinone methides ( $p$-QMs) for the construction of diaryl phosphonates under metal-free conditions. Nonetheless, the di-tert-butyl group 
on $p$-QM derivatives, which needs extra removal steps, may decrease the synthetic value of the product. Very recently, Kang and co-workers [27] developed the Brønsted acid catalyzed phospha-Michael addition reaction of trialkylphosphites with the ortho-quinone methides (o-QMs) in situ generated from $o$-hydroxybenzyl alcohols. This strategy needs a catalytic amount of Brønsted acid based on $N$-heterocyclic phosphorodiamidic acids (NHPAs) that should be synthesized from $N$-phosphonyl chloride, which limited its application. Consequently, metal-free and easy operating methods for the synthesis of diarylmethyl phosphine oxides are still highly desirable. Considering the well-documented nucleophilic addition reactions with secondary phosphine oxides $\left(\mathrm{R}_{2} \mathrm{P}(\mathrm{O}) \mathrm{H}\right)$, we hypothesized that the direct phospha-Michael addition of $\mathrm{R}_{2} \mathrm{P}(\mathrm{O}) \mathrm{H}$ to $o$-QMs would be an attractive way to construct diarylmethyl phosphine oxides with both Lewis base and Brønsted acid functional groups (Scheme 1b).<smiles>O=P(O)(c1ccccc1)c1ccc2ccccc2c1-c1c(P(=O)(O)c2ccccc2)ccc2ccccc12</smiles>

A: BINAPO

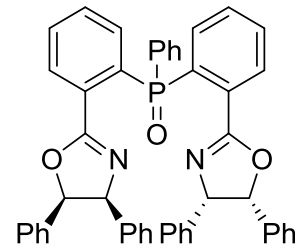

B: Ligand

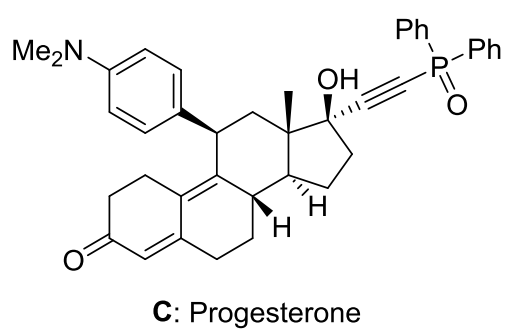<smiles>O=P1(C(c2ccccc2)c2ccccc2)OCC2(CO1)COP(=O)(C(c1ccccc1)c1ccccc1)OC2</smiles>

D: Flame-retardant

Figure 1. Some organophosphorus compounds.

In general, secondary phosphine oxides exist in two tautomeric forms, i.e., the most stable and dominant phosphane oxide isomer (form A), and the phosphinous acid isomer (form $\mathbf{B}$ ), which is the nucleophilic form (Scheme 1b) $[28,29]$. The equilibrium toward the active phosphinous acid form $\mathbf{B}$ should be promoted by the presence of a base. In addition, due to the wide application of $o$-QMs in organic synthetic chemistry, several methods have been successfully developed for the generation of $o$-QMs, including oxidation, acid or base catalysis, etc. [30-43]. Zhou and co-workers developed an efficient base-induced approach for the generation of $o$-QMs via the desulfonylation of 2-tosylalkyl phenols under mild conditions [44-51]. Therefore, we supposed that this direct phospha-Michael addition to $o$-QMs in situ generated from 2-tosylalkyl phenols could be realized under appropriate basic conditions. To fulfill this target, the following obstacles should be considered: firstly, the base employed should promote the formation of $o$-QMs and meanwhile facilitate the equilibrium shifts to nucleophilic active form B; secondly, the reaction rate of phospha-Michael addition must be faster than the dimerization or other nucleophilic reaction of the in situ generated highly reactive o-QMs. In view of the importance of the phosphine oxides, and in order to broaden the application scope of phospha-Michael addition reactions, we report our initial findings toward the construction of bifunctional phosphorus phenols through phospha-Michael addition of diphenylphosphine oxide to the $o$-QMs under basic conditions. 
a) Known Synthetic Methods for Diarylmethyl Phosphine Oxides<smiles>[X]C([Al])[Al]</smiles>

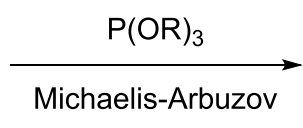

Org. Lett. 2011, 1270.<smiles>OC([Al])[Te]</smiles>

$$
\begin{gathered}
\mathrm{HO}-\mathrm{P}(\mathrm{OR})_{2} \\
\mathrm{FeCl}_{3}
\end{gathered} \underset{\text { Friedel-Crafts Type }}{\longrightarrow}
$$

Eur. J. Org. Chem. 2013, 944.<smiles>[R]OP([O])(=O)C[Al]</smiles><smiles></smiles>

Org. Lett. 2014, 130.<smiles>CC(C)(C)C1=CC(=C[18Br])C=C(C(C)(C)C)C1=O</smiles>

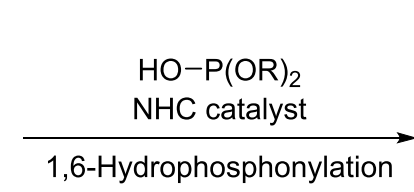<smiles>[R]OP([R])(=O)C([Al])[Al]</smiles><smiles>[R][PH]([R])([18O])C([Al])[Al]</smiles><smiles>[R]P([R])(=O)C([Al])[Al]</smiles><smiles>[R]OP([R])(=O)C([Al])c1cc(C(C)(C)C)c(O)c(C(C)(C)C)c1</smiles>

Org. Biomol. Chem. 2016, 5550.

Org. Lett. 2017, 958.<smiles>Oc1ccccc1C(O)[Al]</smiles><smiles></smiles><smiles>[R]OP([R])(=O)C([Al])c1ccccc1O</smiles>

Org. Lett. 2017, 5988.

b) This Work: Direct Phospha-Michael Addition

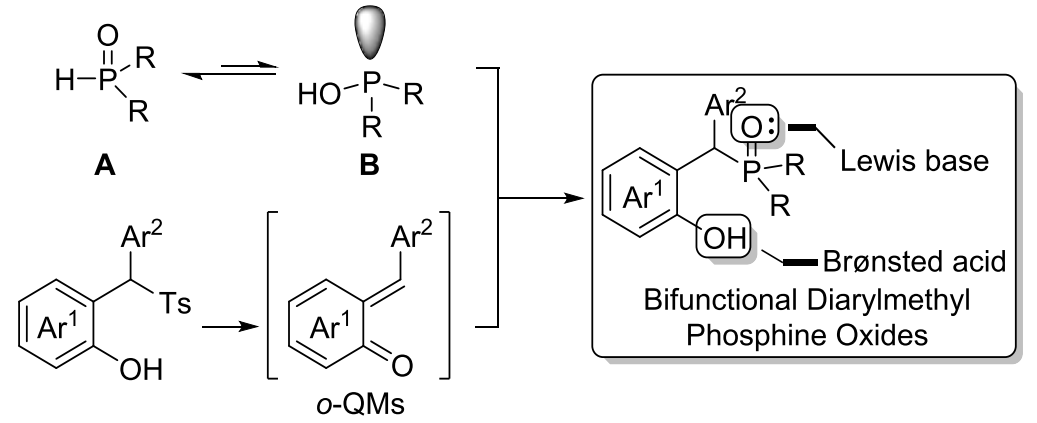

Scheme 1. Synthesis of diarylmethyl phosphine oxides.

\section{Results and Discussion}

With the abovementioned consideration, we initiated our investigation with the readily available 2-(phenyl(tosyl)methyl)phenol 1a and diphenylphosphine oxide 2a in the presence of $\mathrm{K}_{2} \mathrm{CO}_{3}$ (1.2 equiv.) at $60{ }^{\circ} \mathrm{C}$. To our delight, the desired diarylmethyl phosphine oxide product $3 \mathrm{a}$ was isolated in $32 \%$ yield (Table 1, Entry 1). Subsequently, the effects of various solvents on the reactivity were investigated (Entries 1-4). Evaluation of solvents revealed that the transformation was sensitive to the reaction medium; no desired product was achieved with dichloromethane (DCM) or tetrahydrofuran (THF) as the solvent, whereas toluene proved to be the most favorable solvent, giving a promising yield of $36 \%$. Further increasing the reaction temperature to $110{ }^{\circ} \mathrm{C}$, the reactivity was effectively improved and high yield of $92 \%$ was obtained (Entry 6 ). The base played a vital role in the reaction, which promotes the desulfonylation to generate $o-\mathrm{QM}$, meanwhile facilitating the formation of nucleophilic active phosphinous acid form of secondary phosphine oxide. The screening of several other inorganic bases revealed that $\mathrm{K}_{2} \mathrm{CO}_{3}$ remained superior to $\mathrm{Na}_{2} \mathrm{CO}_{3}, \mathrm{Cs}_{2} \mathrm{CO}_{3}$, and $\mathrm{NaOH}$. It is 
worth noting that the weak base $\mathrm{NaHCO}_{3}$ was completely unable to promote this reaction. Therefore, the optimal conditions for this reaction were established by using $\mathrm{K}_{2} \mathrm{CO}_{3}$ (1.2 equiv.) as the base and toluene as the solvent at $110{ }^{\circ} \mathrm{C}$. Then, phosphites including diethyl phosphite and diphenyl phosphite were also investigated as the phosphorus nucleophiles. Disappointingly, no desired products could be isolated under this reaction condition (Entries 11, 12).

Table 1. Optimization for the reaction of 2-(phenyl(tosyl)methyl)-phenol 1a with secondary phosphine oxide $^{a}$.

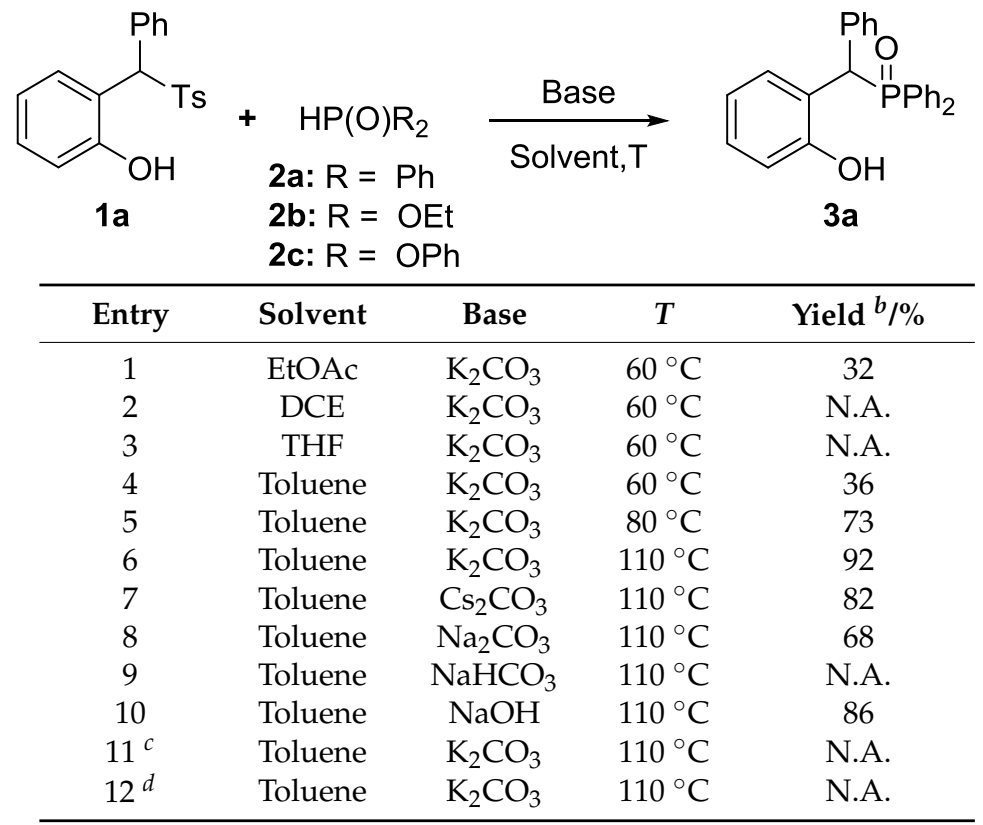

${ }^{a}$ Conditions: $1 \mathbf{a}(0.50 \mathrm{mmol}), \mathbf{2 a}(0.6 \mathrm{mmol})$, Base $(1.2$ equiv. $)$, Solvent $(5 \mathrm{~mL}), 4 \mathrm{~h}$, N.A. $=$ Not Available. ${ }^{b}$ Isolated yields. ${ }^{c} \mathbf{2 b}(0.6 \mathrm{mmol})$ was used instead of $2 \mathbf{a} .^{d} \mathbf{2} \mathbf{c}(0.6 \mathrm{mmol})$ was used instead of $\mathbf{2 a}$.

With the aforementioned reaction conditions maintained, we next sought to explore the scope of the substrate generality. As summarized in Table 2, the transformations proceeded very well and good to excellent yields were achieved. For aryl substituents such as $\mathrm{R}^{1}$, the position of substituents in the aryl ring barely affected the reaction activities (3a-3d). In addition, the electronic property had a slight influence on the reaction yields. For instance, substrates with different substituents (1e, 1f) reacted with diphenylphosphine oxide in $86 \%$ and $80 \%$ yields, respectively. The reaction tolerates both electron-deficient and -donating groups on the benzene ring of the phenols, providing the corresponding products in good yields as well $(\mathbf{3 g}, \mathbf{3 h})$. We also explored the scope of alkyl, aryl-mixed substrates. For example, the 2-(1-tosylethyl)phenol 1i was demonstrated to be a suitable reaction component and provided the target product $3 \mathbf{i}$ in $84 \%$ yield. What is more, the sesamol derived 2-tosylalkyl phenols (1j-11) also proved to be suitable substrates, and provided the corresponding products with good yields.

Furthermore, to illustrate the synthetic utility of the diaryl phosphonate products, we first tested a large-scale experiment with $1 \mathbf{a}(1.0 \mathrm{~g}, 5.0 \mathrm{mmol})$, and it afforded the target adduct $3 \mathrm{a}(1.44 \mathrm{~g})$ in $82 \%$ yield (Scheme 2 ). In consideration of the reports that copolymerization of phosphorus phenols with phenolic resin could be used as preeminent flame retardants [52,53], we transformed 3a to monomers for polymerization reactions. Gratifyingly, the treatment of 3a with acryloyl chloride under basic conditions afforded the phosphorus acrylate 4 in 70\% yield, and thus provided a promising flame-retardant candidate. 
Table 2. Scope for the reaction of 2-tosylalkyl phenols 1 with diphenylphosphine oxide ${ }^{a}$.

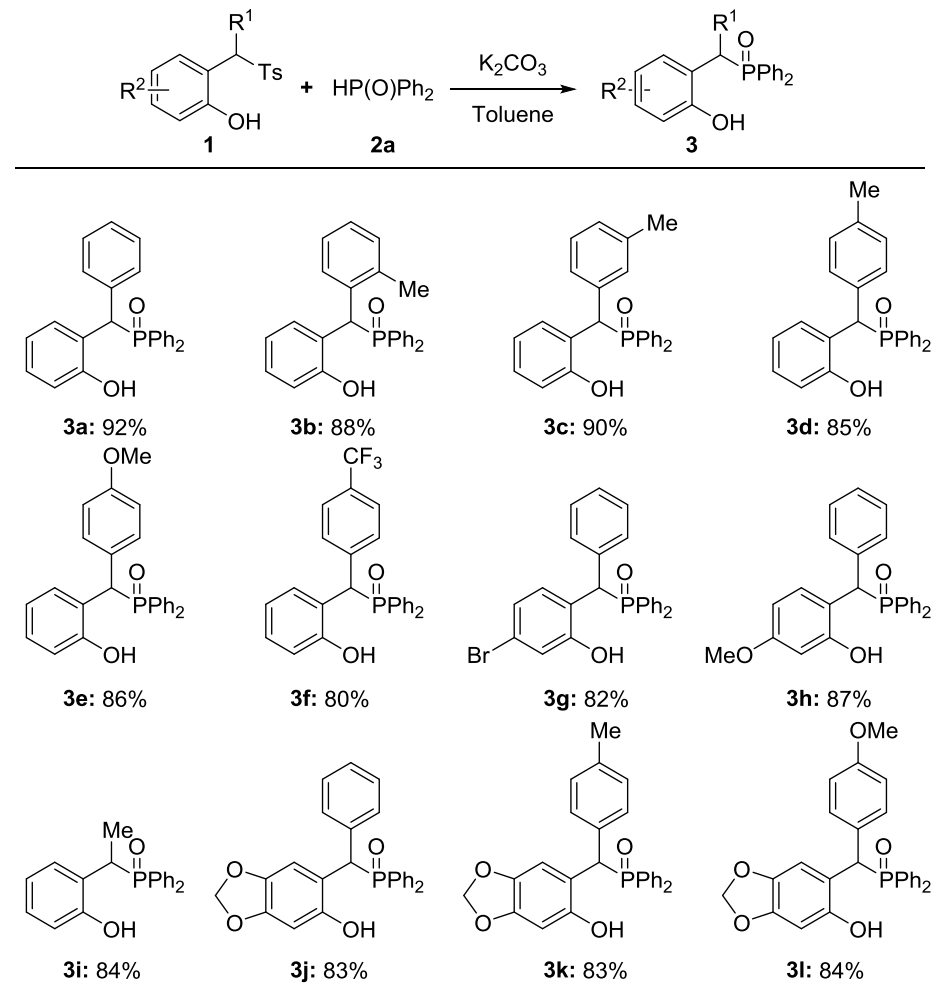

${ }^{a}$ Conditions: 1 (0.50 mmol), $\mathrm{HP}(\mathrm{O}) \mathrm{Ph}_{2}(0.6 \mathrm{mmol}), \mathrm{K}_{2} \mathrm{CO}_{3}$ (1.2 equiv.), Toluene $(5 \mathrm{~mL}), 110{ }^{\circ} \mathrm{C}, 4 \mathrm{~h}$, Isolated yields.

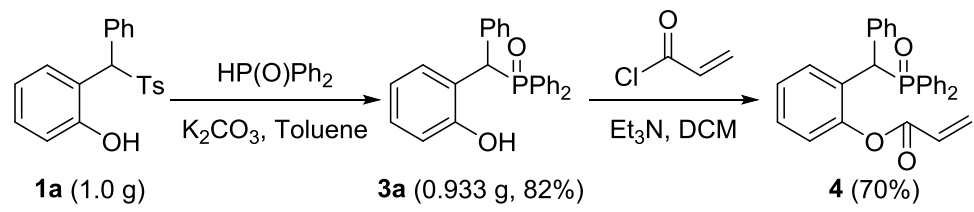

Scheme 2. Large-scale experiment and synthetic transformation.

Based on the above experimental results and previous studies on the formation of $o$-QM under basic conditions reported by Zhou [44-51], a plausible mechanism is depicted in Scheme 3. Firstly, the desulfonylation of 2-(1-tosylalkyl) phenols occurred to generate $o$-QM intermediate in the presence of a suitable base, meanwhile the base promoted the formation of nucleophilic active phosphinous acid $\left(\mathrm{Ph}_{2} \mathrm{POH}\right)$. Subsequently, the phosphinous acid proceeded phospha-Michael addition to the active $o$-QM species and delivering the desired product 3 .

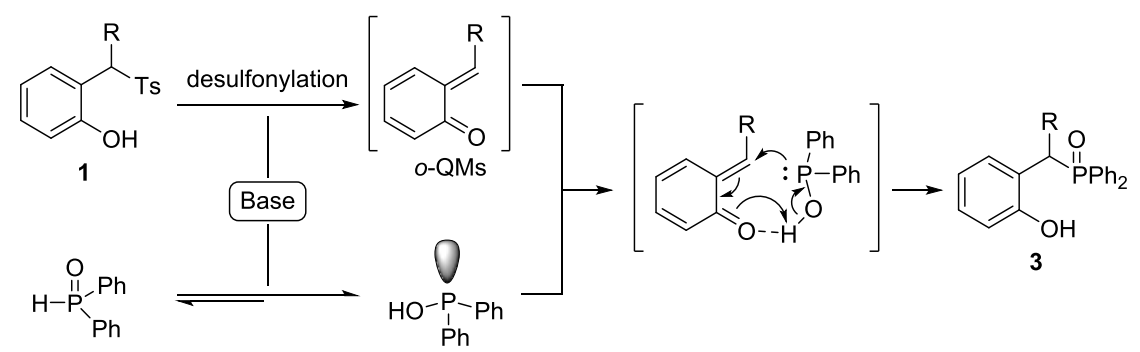

Scheme 3. A plausible mechanism. 


\section{Experimental Section}

General Procedures: A reaction mixture of 2-tosylalkyl phenols $1(0.50 \mathrm{mmol})$, potassium carbonate $(0.6 \mathrm{mmol}, 82.9 \mathrm{mg})$ and diphenylphosphine oxide $(0.6 \mathrm{mmol})$ in toluene $(5 \mathrm{~mL})$ was stirred at $110{ }^{\circ} \mathrm{C}$ for $4 \mathrm{~h}$. Then water $(20 \mathrm{~mL})$ was added to the mixture. The organic layer was separated and the aqueous layer was extracted with dichloromethane $(30 \mathrm{~mL} \times 3)$. The combined organic layer was dried by anhydrous sodium sulfate, concentrated in vacuo. The crude product was purified through column chromatography using dichloromethane and ethyl acetate to give the corresponding product 3.

((2-Hydroxyphenyl)(phenyl)methyl)diphenylphosphine oxide (3a). $176.8 \mathrm{mg}, 92 \%$ yield, unknown compound, pale white solid, m.p.: $238-240{ }^{\circ} \mathrm{C}, \mathrm{R}_{\mathrm{f}}=0.45$ (DCM/EA $\left.=50 / 1\right) ;{ }^{1} \mathrm{H}-\mathrm{NMR}\left(400 \mathrm{MHz}\right.$, DMSO- $\left.d_{6}\right)$ $\delta 9.85(\mathrm{~s}, 1 \mathrm{H}), 8.01(\mathrm{~d}, J=7.6 \mathrm{~Hz}, 1 \mathrm{H}), 7.83-7.77(\mathrm{~m}, 2 \mathrm{H}), 7.75-7.65(\mathrm{~m}, 2 \mathrm{H}), 7.48-7.34(\mathrm{~m}, 8 \mathrm{H}), 7.17-7.13(\mathrm{~m}$, 2H), 7.12-7.03 (m, 1H), 6.96-6.92 (m, 1H), 6.72-6.68 (m, 2H), $5.62\left(\mathrm{~d}, J_{\mathrm{H}-\mathrm{P}}=9.2 \mathrm{~Hz}, 1 \mathrm{H}\right) ;{ }^{13} \mathrm{C}-\mathrm{NMR}(100 \mathrm{MHz}$, DMSO- $\left.d_{6}\right) \delta 154.9\left(\mathrm{~d}, J_{\mathrm{C}-P}=7.9 \mathrm{~Hz}\right), 137.8\left(\mathrm{~d}, J_{\mathrm{C}-P}=4.4 \mathrm{~Hz}\right), 134.1\left(\mathrm{~d}, J_{\mathrm{C}-P}=12.2 \mathrm{~Hz}\right), 133.1\left(\mathrm{~d}, J_{\mathrm{C}-P}=12.4 \mathrm{~Hz}\right)$, $131.9\left(\mathrm{~d}, J_{\mathrm{C}-P}=2.3 \mathrm{~Hz}\right), 131.8\left(\mathrm{~d}, J_{\mathrm{C}-P}=2.3 \mathrm{~Hz}\right), 131.2\left(\mathrm{~d}, J_{\mathrm{C}-P}=8.7 \mathrm{~Hz}\right), 130.9\left(\mathrm{~d}, J_{\mathrm{C}-P}=8.7 \mathrm{~Hz}\right), 130.7(\mathrm{~d}$, $\left.J_{C-P}=5.7 \mathrm{~Hz}\right), 130.3\left(\mathrm{~d}, J_{\mathrm{C}-P}=6.3 \mathrm{~Hz}\right), 128.8\left(\mathrm{~d}, J_{\mathrm{C}-P}=18.5 \mathrm{~Hz}\right), 128.8\left(\mathrm{~d}, J_{\mathrm{C}-P}=4.1 \mathrm{~Hz}\right), 128.5,128.4,126.9$, $125.0\left(\mathrm{~d}, J_{C-P}=3.1 \mathrm{~Hz}\right), 119.5,115.7,43.2\left(\mathrm{~d}, J_{\mathrm{C}-P}=68.2 \mathrm{~Hz}\right) ;{ }^{31} \mathrm{P}-\mathrm{NMR}\left(162 \mathrm{MHz}, \mathrm{DMSO}-d_{6}\right) \delta 31.3$; IR $(\mathrm{KBr}):$ $3413,3058,1576,1485,1437,1275,1248,1144,1119,811,750,691,560,530$; HRMS (ESI) calcd for $\mathrm{C}_{25} \mathrm{H}_{22} \mathrm{O}_{2} \mathrm{P}$ $[(\mathrm{M}+\mathrm{H})]^{+}:$385.1352, found: 385.1352 .

\section{Conclusions}

In conclusion, we have developed a concise protocol for the rapid synthesis of bifunctional phosphorus phenols by using diphenylphosphine oxide and 2-(1-tosylalkyl) phenols via the phospha-Michael addition of organophosphorus compounds to in situ generated $o$-QM intermediates under basic condition. This work broadens the scope of phospha-Michael addition reactions that can be employed in the synthesis of diarylmethyl phosphine oxides. Further investigations into the synthetic applications of existing phosphorus phenols are ongoing in our laboratory.

Author Contributions: Z.C. and J.H. conceived and designed the experiments; Z.C. and Q.S. performed the experiments and wrote the paper draft; G.W. and S.C. help to analyze the data of new compounds.

Funding: This work was supported by the National Natural Science Foundation of China (21702026) and the Fundamental Research Funds for the Central Universities (N160503001, N160504001).

Acknowledgments: The authors thank Yong-Gui Zhou for helpful discussion.

Conflicts of Interest: The authors declare no conflict of interest.

\section{References}

1. Duke, S.O.; Powles, S.B. Glyphosate: A once-in-a-century herbicide. Pest Manag. Sci. 2008, 64, 319-325. [CrossRef] [PubMed]

2. Martin, R.; Buchwald, S.L. Palladium-Catalyzed Suzuki-Miyaura Cross-Coupling Reactions Employing Dialkylbiaryl Phosphine Ligands. Acc. Chem. Res. 2008, 41, 1461-1473. [CrossRef] [PubMed]

3. McGrath, J.W.; Chin, J.P.; Quinn, J.P. Organophosphonates revealed: New insights into the microbial metabolism of ancient molecules. Nat. Rev. Microbiol. 2013, 11, 412-419. [CrossRef] [PubMed]

4. Mucha, A.; Kafarski, P.; Berlicki, Ł. Remarkable Potential of the $\alpha$-Aminophosphonate/Phosphinate Structural Motif in Medicinal Chemistry. J. Med. Chem. 2011, 54, 5955-5980. [CrossRef] [PubMed]

5. Grushin, V.V. Mixed Phosphine-Phosphine Oxide Ligands. Chem. Rev. 2004, 104, 1629-1662. [CrossRef] [PubMed]

6. Lam, F.L.; Kwong, F.Y.; Chan, A.S.C. Chiral Phosphorus Ligands with Interesting Properties and Practical Applications. Top. Organomet. Chem. 2011, 36, 29-66.

7. Ma, J.-A. Catalytic asymmetric synthesis of $\alpha$ - and $\beta$-amino phosphonic acid derivatives. Chem. Soc. Rev. 2006, 35, 630-636. [CrossRef] [PubMed] 
8. Shie, J.J.; Fang, J.M.; Wang, S.Y.; Tsai, K.C.; Cheng, S.E.; Yang, A.S.; Hsiao, S.C.; Su, C.Y.; Wong, C.H. Synthesis of Tamiflu and its Phosphonate Congeners Possessing Potent Anti-Influenza Activity. J. Am. Chem. Soc. 2007, 129, 11892-11893. [CrossRef] [PubMed]

9. Allen, D.W. Phosphines and related P-C-bonded Compounds. Organophosphorus Chem. 2012, 41, 1-55.

10. Ogawa, C.; Sugiura, M.; Kobayashi, S. Stereospecific, Enantioselective Allylation of $\alpha$-Hydrazono Esters by Using Allyltrichlorosilanes with BINAP Dioxides as Neutral-Coordinate Organocatalysts. Angew. Chem. Int. Ed. 2004, 43, 6491-6493. [CrossRef] [PubMed]

11. Horsman, G.P.; Zechel, D.L. Phosphonate Biochemistry. Chem. Rev. 2017, 117, 5704-5783. [CrossRef] [PubMed]

12. Tokuoka, E.; Kotani, S.; Matsunaga, H.; Ishizuka, T.; Hashimoto, S.; Nakajima, M. Asymmetric ring opening of meso-epoxides catalyzed by the chiral phosphine oxide BINAPO. Tetrahedron Asymmetry 2005, 16, 2391-2392. [CrossRef]

13. Jin, Y.; Du, D.M. The synthesis of phosphine oxide-linked bis(oxazoline) ligands and their application in asymmetric allylic alkylation. Tetrahedron 2012, 68, 3633-3640. [CrossRef]

14. Jiang, W.-Q.; Allan, G.; Chen, X.; Fiordeliso, J.J.; Linton, O.; Tannenbaum, P.; Xu, J.; Zhu, P.-F.; Gunnet, J.; Demarest, K.; et al. Novel phosphorus-containing $17 \beta$-side chain mifepristone analogues as progesterone receptor antagonists. Steroids 2006, 71, 949-954. [CrossRef] [PubMed]

15. Harada, T.; Yamanaka, Y.; Matsushita, Y.; Fukushima, K. Flame Retardant Resin Composition and Molded Product. EP2681281A12014, 1 March 2011.

16. Merino, P.; Marqués-López, E.; Herrera, R.P. Catalytic Enantioselective Hydrophosphonylation of Aldehydes and Imines. Adv. Synth. Catal. 2008, 350, 1195-1208. [CrossRef]

17. Van der Jeught, S.; Stevens, C.V. Direct Phosphonylation of Aromatic Azaheterocycles. Chem. Rev. 2009, 109, 2672-2702. [CrossRef] [PubMed]

18. Albrecht, L.; Albrecht, A.; Krawczyk, H.; Jørgensen, K.A. Organocatalytic Asymmetric Synthesis of Organophosphorus Compounds. Chem. Eur. J. 2010, 16, 28-48. [CrossRef] [PubMed]

19. Demmer, C.S.; Krogsgaard-Larsen, N.; Bunch, L. Review on Modern Advances of Chemical Methods for the Introduction of a Phosphonic Acid Group. Chem. Rev. 2011, 111, 7981-8006. [CrossRef] [PubMed]

20. Zhao, D.; Wang, R. Recent developments in metal catalyzed asymmetric addition of phosphorus nucleophiles. Chem. Soc. Rev. 2012, 41, 2095-2108. [CrossRef] [PubMed]

21. Bhattacharya, A.K. Michaelis-Arbuzov rearrangement. Chem. Rev. 1981, 81, 415-430. [CrossRef]

22. Rajeshwaran, G.G.; Nandakumar, M.; Sureshbabu, R.; Mohanakrishnan, A.K. Lewis Acid-Mediated Michaelis-Arbuzov Reaction at Room Temperature: A Facile Preparation of Arylmethyl/Heteroarylmethyl Phosphonates. Org. Lett. 2011, 13, 1270-1273. [CrossRef] [PubMed]

23. Pallikonda, G.; Chakravarty, $\mathrm{M}$. $\mathrm{FeCl}_{3}$-Mediated Arylation of $\alpha$-Hydroxyphosphonates with Unactivated Arenes: Pseudo-Umpolung in Allylic Phosphonates. Eur. J. Org. Chem. 2013, 2013, 944-951. [CrossRef]

24. Montel, S.; Jia, T.; Walsh, P.J. Palladium-Catalyzed $\alpha$-Arylation of Benzylic Phosphine Oxides. Org. Lett. 2014, 16, 130-133. [CrossRef] [PubMed]

25. Arde, P.; Anand, R.V. N-Heterocyclic carbene catalysed 1,6-hydrophosphonylation of $p$-quinone methides and fuchsones: An atom economical route to unsymmetrical diaryl- and triarylmethyl phosphonates. Org. Biomol. Chem. 2016, 14, 5550-5554. [CrossRef] [PubMed]

26. Molleti, N.; Kang, J.Y. Synthesis of Diaryl Diazaphosphonates via 1,6-Hydrophosphonylation of $p$-Quinone Methides with N-Heterocyclic Phosphine-Thioureas. Org. Lett. 2017, 19, 958-961. [CrossRef] [PubMed]

27. Huang, H.; Kang, J.Y. Organocatalytic Phosphonylation of in situ Formed o-Quinone Methides. Org. Lett. 2017, 19, 5988-5991. [CrossRef] [PubMed]

28. Chatt, J.; Heaton, B.T. The hydrolysis of monochlorophosphine and monochloroarsine complexes of platinum (II): Bridging phosphinato- and arsinato-groups. J. Chem. Soc. A 1968, 0, 2745-2757. [CrossRef]

29. Ivanova, N.I.; Gusarova, N.K.; Nikitina, E.A.; Albanov, A.I.; Sinegovskaya, L.M.; Nikitin, M.V.; Konovalova, N.A.; Trofimov, B.A. Chemo- and stereoselective addition of diorganylphosphine oxides to $\alpha, \beta$-ethylenic aldehydes. Phosphorus Sulfur Silicon Relat. Elem. 2004, 179, 7-18. [CrossRef]

30. Van de Water, R.W.; Pettus, T.R.R. o-Quinone methides: Intermediates underdeveloped and underutilized in organic synthesis. Tetrahedron 2002, 58, 5367-5405. [CrossRef]

31. Willis, N.J.; Bray, C.D. ortho-Quinone Methides in Natural Product Synthesis. Chem. Eur. J. 2012, 18, 9160-9173. [CrossRef] [PubMed] 
32. Angle, S.R.; Yang, W. Synthesis and chemistry of a quinone methide model for anthracycline antitumor antibiotics. J. Am. Chem. Soc. 1990, 112, 4524-4528. [CrossRef]

33. Rodriguez, R.; Moses, J.E.; Adlington, R.M.; Baldwin, J.E. A new and efficient method for o-quinone methide intermediate generation: Application to the biomimetic synthesis of the benzopyran derived natural products $( \pm)$-lucidene and ( \pm )-alboatrin. Org. Biomol. Chem. 2005, 3, 3488-3495. [CrossRef] [PubMed]

34. Weinert, E.E.; Dondi, R.; Colloredo-Melz, S.; Frankenfield, K.N.; Mitchell, C.H.; Freccero, M.; Rokita, S.E. Substituents on Quinone Methides Strongly Modulate Formation and Stability of Their Nucleophilic Adducts. J. Am. Chem. Soc. 2006, 128, 11940-11947. [CrossRef] [PubMed]

35. Bray, C.D. Generation and hetero-Diels-Alder reactions of an $o$-quinone methide under mild, anionic conditions: Rapid synthesis of mono-benzannelated spiroketals. Org. Biomol. Chem. 2008, 6, 2815-2819. [CrossRef] [PubMed]

36. Bray, C.D. An Approach to Benzannelated [5,6]-Spiroketals. Synlett 2008, 2500-2502. [CrossRef]

37. Arumugam, S.; Popik, V.V. Photochemical Generation and the Reactivity of $o$-Naphthoquinone Methides in Aqueous Solutions. J. Am. Chem. Soc. 2009, 131, 11892-11899. [CrossRef] [PubMed]

38. Basarić, N.; Cindro, N.; Hou, Y.; Žabčić, I.; Mlinarić-Majerski, K.; Wan, P. Competing photodehydration and excited-state intramolecular proton transfer (ESIPT) in adamantyl derivatives of 2-phenylphenols. Can. J. Chem. 2011, 89, 221-234. [CrossRef]

39. Green, J.C.; Jimnez-Alonso, S.; Brown, E.R.; Pettus, T.R.R. Total Synthesis and Repudiation of the Helianane Family. Org. Lett. 2011, 13, 5500-5503. [CrossRef] [PubMed]

40. Pathak, T.P.; Sigman, M.S. Applications of ortho-Quinone Methide Intermediates in Catalysis and Asymmetric Synthesis. J. Org. Chem. 2011, 76, 9210-9215. [CrossRef] [PubMed]

41. Percivalle, C.; La Rosa, A.; Verga, D.; Doria, F.; Mella, M.; Palumbo, M.; Di Antonio, M.; Freccero, M. Quinone Methide Generation via Photoinduced Electron Transfer. J. Org. Chem. 2011, 76, 3096-3106. [CrossRef] [PubMed]

42. Radomkit, S.; Sarnpitak, P.; Tummatorn, J.; Batsomboon, P.; Ruchirawat, S.; Ploypradith, P. Pt(IV)-catalyzed generation and [4+2]-cycloaddition reactions of o-quinone methides. Tetrahedron 2011, 67, 3904-3914. [CrossRef]

43. Majumdar, N.; Korthals, K.A.; Wulff, W.D. Simultaneous Synthesis of Both Rings of Chromenes via a Benzannulation/o-Quinone Methide Formation/Electrocyclization Cascade. J. Am. Chem. Soc. 2012, 134, 1357-1362. [CrossRef] [PubMed]

44. Chen, M.-W.; Cao, L.-L.; Ye, Z.-S.; Jiang, G.-F.; Zhou, Y.-G. A mild method for generation of $o$-quinone methides under basic conditions. The facile synthesis of trans-2,3-dihydrobenzofurans. Chem. Commun. 2013, 49, 1660. [CrossRef] [PubMed]

45. Wu, B.; Gao, X.; Chen, M.-W.; Zhou, Y.-G. A Concise Synthesis of 2-(2-Hydroxyphenyl)acetonitriles via the o-Quinone Methides Generated from 2-(1-Tosylalkyl)phenols. Chin. J. Chem. 2014, 32, 981-984. [CrossRef]

46. Wu, B.; Gao, X.; Yan, Z.; Chen, M.-W.; Zhou, Y.-G. C-H Oxidation/Michael Addition/Cyclization Cascade for Enantioselective Synthesis of Functionalized 2-Amino-4H-chromenes. Org. Lett. 2015, 17, 6134-6137. [CrossRef] [PubMed]

47. Wu, B.; Gao, X.; Yan, Z.; Huang, W.-X.; Zhou, Y.-G. Enantioselective synthesis of functionalized 2-amino- $4 H$-chromenes via the $o$-quinone methides generated from 2-(1-tosylalkyl)phenols. Tetrahedron Lett. 2015, 56, 4334-4338. [CrossRef]

48. Guo, W.; Wu, B.; Zhou, X.; Chen, P.; Wang, X.; Zhou, Y.-G.; Liu, Y.; Li, C. Formal Asymmetric Catalytic Thiolation with a Bifunctional Catalyst at a Water-Oil Interface: Synthesis of Benzyl Thiols. Angew. Chem. Int. Ed. 2015, 54, 4522-4526. [CrossRef] [PubMed]

49. Wu, B.; Gao, X.; Chen, M.-W.; Zhou, Y.-G. Direct amination of 2-(1-tosylalkyl)phenols with aqueous ammonia: A metal-free synthesis of primary amines. Tetrahedron Lett. 2015, 56, 1135-1137. [CrossRef]

50. Wu, B.; Yu, Z.; Gao, X.; Lan, Y.; Zhou, Y.-G. Regioselective $\alpha$-Addition of Deconjugated Butenolides: Enantioselective Synthesis of Dihydrocoumarins. Angew. Chem. Int. Ed. 2017, 56, 4006-4010. [CrossRef] [PubMed]

51. Zhou, J.; Wang, M.-L.; Gao, X.; Jiang, G.-F.; Zhou, Y.-G. Bifunctional squaramide-catalyzed synthesis of chiral dihydrocoumarins via ortho-quinone methides generated from 2-(1-tosylalkyl)phenols. Chem. Commun. 2017, 53, 3531. [CrossRef] [PubMed] 
52. Nakamoto, Y.; Hirotsu, K.; Yamada, S. Phosphorus-Containing Curable Resin Compositions and Cured Products Thereof with Excellent Fire and Hydrolysis Resistance. JP2013095818, 20 May 2013.

53. Nakamoto, Y.; Hirotsu, K.; Yamada, S. Diarylphosphine Oxides Bearing Oxyphenyl Groups, Diarylphosphoryl Alcohols as Their Intermediates, Manufacture of Them and Intermediates, Fireproofing Agents Containing Them, and Monomers for Fire-Resistant Resins. WO2012039473, 29 March 2012.

Sample Availability: Samples of the compounds $\mathbf{3 a}-\mathbf{j}$ and 4 are available from the authors.

(C) 2018 by the authors. Licensee MDPI, Basel, Switzerland. This article is an open access article distributed under the terms and conditions of the Creative Commons Attribution (CC BY) license (http://creativecommons.org/licenses/by/4.0/). 